\title{
Chemical and Biological Properties of Lipopolysaccharide, Lipid A and Degraded Polysaccharide from Wolinella recta ATCC 33238
}

\author{
By HIDEFUMI KUMADA, ${ }^{1}$ KIYOKO WATANABE, ${ }^{1}$

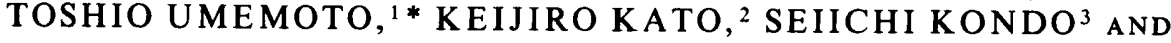 \\ KAZUHITO HISATSUNE ${ }^{3}$ \\ ${ }^{1}$ Department of Oral Microbiology, Kanagawa Dental College, 82 Inaoka-cho, Yokosuka, \\ Kanagawa 238, Japan \\ 2 Department of Oral Microbiology, Okayama University Dental School, 2-5-1 Shikata-cho, \\ Okayama 700, Japan \\ ${ }^{3}$ Department of Microbiology, School of Pharmaceutical Sciences, Josai University \\ 1-1 Keyakidai, Sakado, Saitama 350-02, Japan
}

(Received 23 September 1988; revised 4 January 1989; accepted 11 January 1989)

\begin{abstract}
Lipopolysaccharide (LPS) was isolated and purified from Wolinella recta ATCC 33238 by the phenol-water procedure and RNAase treatment. The sugar components of the LPS were rhamnose, mannose, glucose, heptose, 2-keto-3-deoxyoctonate (KDO) (3-deoxy-D-mannooctulosonate) and glucosamine. The degraded polysaccharide prepared from LPS by mild acid hydrolysis was fractionated by Sephadex G-50 gel chromatography into three fractions: (1) a high-molecular-mass fraction, eluting just behind the void volume, consisting of a long chain of rhamnose ( 22 mols per 3 mols of heptose residue) with attached core oligosaccharide; (2) a core oligosaccharide containing heptose, glucose and KDO, substituted with a short side chain of rhamnose; (3) a low-molecular-mass fraction containing KDO and phosphate. The main fatty acids of the lipid $A$ were $\mathrm{C}_{12: 0}, \mathrm{C}_{14: 0}, 3-\mathrm{OH}-\mathrm{C}_{14: 0}$ and 3-OH- $\mathrm{C}_{16: 0}$. The biological activities of the LPS were similar to those of Salmonella typhimurium LPS in activation of the clotting enzyme of Limulus amoebocytes, the Schwartzman reaction and mitogenicity for murine lymphocytes, although all the biological activities of lipid A were lower than those of intact LPS.
\end{abstract}

\section{INTRODUCTION}

Previous evidence has shown that the characteristic microbial complexes from different forms of destructive periodontal diseases play a specific aetiological role. For instance, Bacteroides gingivalis is associated with advanced destructive periodontitis in certain individuals (Slots, 1982) and Bacteroides intermedius with acute necrotizing ulcerative gingivitis (Chung $e t$ al., 1983). In lesions of juvenile periodontitis, Actinobacillus actinomycetemcomitans is particularly likely to be detected (Zambon et al., 1983). On the other hand, several investigators showed that the proportion of motile rods is much higher in active periodontal disease sites than in inactive sites (Listgarten, 1982; Savitt \& Socransky, 1984).

Tanner et al. (1984) recently isolated an asaccharolytic, Gram-negative, motile rod, which was named Wolinella recta, from periodontal pockets of patients with advanced destructive periodontal disease. In some lesions, this bacterium was isolated as the numerically dominant species (Moore et al., 1982, 1984; Dzink et al., 1985); however, there is no direct evidence of the periodontopathic potential of this bacterium. Grenier \& Mayrand (1986) also reported nutritional relationships between $W$. recta and $B$. gingivalis or Bacteroides melaninogenicus; for instance, $W$. recta produces a protohaem that stimulates the growth of $B$. gingivalis or $B$. melaninogenicus, and $B$. melaninogenicus produces formate, which stimulates the growth of $W$. recta.

Abbreviations: DPS, degraded polysaccharide; KDO, 2-keto-3-deoxyoctonate (3-deoxy-D-manno-octulosonate). 
It has been speculated that numerous surface components of periodontopathic bacteria act as virulence factors that probably cause host tissue destruction in periodontal disease. In the present study, the chemical composition and biological activity of $W$. recta lipopolysaccharide (LPS) together witheits degraded polysaccharide and lipid A were investigated.

A preliminary account of this study was published by Kumada et al. (1987).

\section{METHODS}

Organism and cultivation. $W$. recta ATCC 33238 was grown to early stationary phase in Schaedler broth (BBL Microbiology Systems) supplemented with formate $(0.2 \%, \mathrm{w} / \mathrm{v})$ and fumarate $(0.3 \%, \mathrm{w} / \mathrm{v})$ at $37^{\circ} \mathrm{C}$ in an anaerobic chamber containing $70 \% \mathrm{~N}_{2}, 15 \% \mathrm{H}_{2}$ and $15 \% \mathrm{CO}_{2}$ (by vol.). The bacterial cells were inactivated by heating at $121^{\circ} \mathrm{C}$ for $20 \mathrm{~min}$, and then washed three times with distilled water and dried with acetone.

Preparation of LPS. LPS was extracted from the acetone-dried cells by the phenol/water technique of Westphal et al. (1952). It was purified by repeated ultracentrifugation $(105000 \mathrm{~g}$ for $10 \mathrm{~h})$ after each washing before and after RNAase treatment (Westphal \& Jann, 1966) and was then lyophilized. LPSs of Salmonella typhimurium LT2 and Salmonella minnesota R595 were obtained by Westphal's phenol/water method and Galanos's phenol/chloroform/light petroleum method (Galanos et al., 1969), respectively.

Degradation of LPS. LPS was hydrolysed with $5 \%(\mathrm{v} / \mathrm{v})$ acetic acid $\left(10 \mathrm{mg} \mathrm{m}^{-1}\right)$ at $100^{\circ} \mathrm{C}$ for $7.5 \mathrm{~h}$; the resulting insoluble material was removed by centrifugation $(15000 \mathrm{~g}, 10 \mathrm{~min})$, washed three times with distilled water and then lyophilized to obtain lipid $A$. The supernatant and the first washings were combined and rotary-evaporated under reduced pressure to dryness yielding degraded polysaccharide (DPS). Yields of DPS and lipid A from LPS were $76.1 \%(w / w)$ and $16.9 \%(w / w)$, respectively.

Analytical methods. Total carbohydrate was measured by the phenol/sulphuric acid method (Dubois et al., 1956), and total phosphorus and amino sugar were determined as described by Hisatsune et al. (1967). Heptose was determined either by the method of Osborn (1963) or by GLC. Protein was assayed by the method of Bradford (1976). 2-Keto-3-deoxyoctonate (KDO) (3-deoxy-D-manno-octulosonate) was estimated by the conventional Weissbach periodate/thiobarbituric acid reaction under conventional hydrolysis conditions $\left(0.01 \mathrm{M}-\mathrm{H}_{2} \mathrm{SO}_{4}\right.$ at $100^{\circ} \mathrm{C}$ for $20 \mathrm{~min}$ ) (Weissbach \& Hurwitz, 1959). KDO (ammonium salt) used as a standard was purchased from Sigma. Total lipid was measured by weighing the ether-soluble fraction after hydrolysis of LPS in $4 \mathrm{M}-\mathrm{HCl}$ at $100^{\circ} \mathrm{C}$ for $4 \mathrm{~h}$.

Neutral sugars were determined after hydrolysis in $2 \mathrm{M}$-trifluoroacetic acid at $120^{\circ} \mathrm{C}$ for $1 \mathrm{~h}$ by GLC as alditol acetates according to the method of Laine et al. (1974) (column: $3 \%$ ECNSS-M coated on Chromosorb W, $3 \mathrm{~mm} \times 2 \mathrm{~m}$; Gasukuro Kogyo Co., Japan) using xylose as an internal standard. For amino sugar determination, samples were hydrolysed in $4 \mathrm{M}-\mathrm{HCl}$ at $100^{\circ} \mathrm{C}$ for $8 \mathrm{~h}$, and the hydrolysates were fractionated on a Dowex $50\left(\mathrm{H}^{+}\right)$ column by the method of Wheat (1966). The amino sugar fraction thus separated was $N$-acetylated by the method of Laine et al. (1974). Amino sugars were then determined as $N$-acetylalditol acetates by GLC (column: TABSORB, $3 \mathrm{~mm} \times 2 \mathrm{~mm}$; Regis Chemical Co., USA) using mannose as an internal standard. Fatty acids released by heating in $4 \mathrm{M}-\mathrm{HCl}$ at $100^{\circ} \mathrm{C}$ for $4 \mathrm{~h}$ and then in $1 \mathrm{M}-\mathrm{NaOH}$ at $100^{\circ} \mathrm{C}$ for $2 \mathrm{~h}$ (Haeffner et al., 1977) were esterified with diazomethane (Rietschel et al., 1972) and then analysed by GLC (column: $25 \%$ DEGS, $3 \mathrm{~mm} \times 2 \mathrm{~m}$; Gasukuro Kogyo Co.). Methylnonadecanoate was used as an internal standard. Neutral and amino sugars and fatty acids were identified by their retention times in GLC and their mass spectra in GLC/MS as compared with those of authentic standards. GLC/MS spectrometry was done on a JEOL DX-300 with the same column as described above. All analytical data are expressed as the mean values of three experiments.

Gel filtration of DPS $(110 \mathrm{mg})$ was done with a Sephadex G-50 column $(1.6 \times 100 \mathrm{~cm})$ with pyridine/acetic acid/water $\left(10: 4: 1000\right.$, by vol.) used as solvent at a flow rate of $13 \mathrm{ml} \mathrm{h}^{-1}$; fractions $(1 \mathrm{ml})$ of the eluate were collected. The eluate was monitored with a refractive index detector (RID-6A; Shimadzu).

SDS-PAGE. This was done according to the method of Laemmli (1970) using slab gels $(14 \times 12 \mathrm{~cm})$. The separating gel contained $14 \%(\mathrm{w} / \mathrm{v})$ acrylamide and the stacking gel contained $4 \%(\mathrm{w} / \mathrm{v})$ acrylamide. LPS samples in water were mixed with an equal volume of $0.1 \mathrm{M}$-Tris/ $\mathrm{HCl}$ buffer $(\mathrm{pH} 6.8)$ containing $2 \%(\mathrm{w} / \mathrm{v}) \mathrm{SDS}, 20 \%(\mathrm{w} / \mathrm{v})$ sucrose, $1 \%(\mathrm{w} / \mathrm{v}) 2$-mercaptoethanol and $0.001 \%(\mathrm{w} / \mathrm{v})$ bromophenol blue. The mixtures were incubated for $5 \mathrm{~min}$ at $100{ }^{\circ} \mathrm{C}$, and $10 \mu \mathrm{l}$ samples were applied to each well of the gel and subjected to electrophoresis at constant current ( $30 \mathrm{~mA}$ per gel) until the dye had migrated to the bottom of the gel. LPSs on the gel were detected by the silver stain method of Tsai \& Frasch (1982).

Limulus test. For Limulus amoebocyte lysate clotting activity, $200 \mu \mathrm{l}$ of Toxicolour system reagent (LS-20 set; Seikagaku Kogyo Co., Japan) (Iwanaga et al., 1978) and $20 \mu \mathrm{l}$ of diluted samples (LPS, DPS and lipid A) were incubated for $30 \mathrm{~min}$ at $37^{\circ} \mathrm{C}$. Lipid A was dissolved in $0.5 \%(\mathrm{v} / \mathrm{v})$ triethylamine. The reaction was stopped by placing the tube in an ice-bath and adding $0.4 \mathrm{ml} 0.8 \mathrm{M}$-acetic acid, and the $A_{405}$ was then measured. The minimum dose of LPS for a positive reaction was determined as the amount giving an $A_{405}>0 \cdot 1$. S. typhimurium LPS (Sigma) was used as positive control. 
Schwartzman assay. The dermal Schwartzman assay was done by injecting three male Japanese White rabbits $(1.5$ to $2.0 \mathrm{~kg}$ ) intradermally in the shaved abdomen with 1,10 and $100 \mu \mathrm{g}$ doses of samples in $0.1 \mathrm{ml}$ of Dulbecco's phosphate-buffered saline (Nissui Pharmaceutical Co., Japan), followed $24 \mathrm{~h}$ later by a provoking intravenous injection of $100 \mu \mathrm{g} S$. typhimurium LPS in $0.1 \mathrm{ml}$ of Dulbecco's phosphate-buffered saline. The injection sites were examined for haemorrhagic necrosis $5 \mathrm{~h}$ after injection of the provoking dose.

Mitogenic activity. Spleen cells from $\mathrm{C} 3 \mathrm{H} / \mathrm{HeJ}$ and $\mathrm{C} 3 \mathrm{H} / \mathrm{HeN}$ mice were suspended in RPMI 1640 medium (Gibco) supplemented with penicillin $\left(100 \mathrm{U} \mathrm{ml}^{-1}\right)$, streptomycin $\left(100 \mu \mathrm{g} \mathrm{ml}^{-1}\right)$ and $20 \%(\mathrm{v} / \mathrm{v})$ foetal calf serum (Gibco). Lymphoid cells were cultured in a 96-well microculture plate containing various amounts of samples or concanavalin A (Sigma), at $37^{\circ} \mathrm{C}$ in a humidified $5 \%(\mathrm{v} / \mathrm{v}) \mathrm{CO}_{2}$ atmosphere. Cultures were pulsed with $0.5 \mu \mathrm{Ci}$ $(18.5 \mathrm{kBq})\left[{ }^{3} \mathrm{H}\right]$ thymidine $\left(\left[{ }^{3} \mathrm{H}\right] \mathrm{TdR}\right)\left[18.2 \mathrm{Ci} \mathrm{mmol}^{-1}(673 \mathrm{TBq} \mathrm{mmol}-1)\right.$; New England Nuclear] during the final $24 \mathrm{~h}$ of a $72 \mathrm{~h}$ incubation period. Cells were then harvested, and the incorporation of $\left[{ }^{3} \mathrm{H}\right]$ thymidine by the cultured cells was measured with a liquid scintillation counter. The minimum mitogenic response was set as that in which the stimulation index was higher than the index of the maximum response of $\mathrm{C} 3 \mathrm{H} / \mathrm{HeJ}$ mouse spleen cells when subjected to the range of concentrations of LPS tested.

\section{RESULTS AND DISCUSSION}

\section{Extraction yield and overall chemical composition}

In the preliminary experiments, the yield of crude LPS was small when extracts were ultracentrifuged for $3 \mathrm{~h}$. The period of centrifugation was therefore extended to $10 \mathrm{~h}$. The crude LPS preparations obtained by ultracentrifugation for 3 and $10 \mathrm{~h}$ showed the same chemical composition overall and the same content of neutral and amino sugars determined by GLC. The yield of the purified LPS from the acetone-dried cells was $0.9 \%(w / w)$. When the purified LPS, dissolved in distilled water, was scanned from 190 to $310 \mathrm{~nm}$, no absorption peak at either $260 \mathrm{~nm}$ or $280 \mathrm{~nm}$ was observed, indicating that, as far as UV absorption showed, no nucleic acid or protein was present in the LPS as contaminant.

The overall chemical composition of $W$. recta LPS is shown in comparison with that of $S$. typhimurium LT2 in Table 1. The composition of the two LPSs was virtually the same although the total lipid $(16.5 \%)$ of the former was lower than that of the control LPS $(28.9 \%)$. Thus, the overall chemical composition of the $W$. recta LPS was not very different from that of a typical Gram-negative bacterial LPS.

\section{Sugar composition}

In a preliminary experiment, when LPS was treated with $1 \%$ acetic acid for $12 \mathrm{~h}$ at $100{ }^{\circ} \mathrm{C}$, lipid A and DPS were not cleaved. To hydrolyse the LPS, it was necessary to use $5 \%$ acetic acid at $100{ }^{\circ} \mathrm{C}$ for $7.5 \mathrm{~h}$. The results of the sugar analysis of the LPS are in Table 2. Rhamnose, mannose, glucose, L-glycero-D-mannoheptose, D-glycero-D-mannoheptose, KDO and glucosamine were found. Glucose, L-glycero-D-mannoheptose and KDO are usual sugar constituents of the core region of typical Gram-negative bacterial LPS, whereas glucosamine is a basic structural unit of the lipid A backbone of LPS (Rietschel et al., 1982, 1984). It was particularly noted that as much as $29.8 \%$ rhamnose was found in the LPS of $W$. recta. Furthermore, in addition to L-glycero-D-mannoheptose $(5 \cdot 2 \%)$, D-glycero-D-mannoheptose, which has rarely been reported as a component sugar of Gram-negative bacterial LPS (Wilkinson, 1977), was found in considerable amounts $(3.0 \%)$, the molar ratios of the two heptoses being $2: 1 \cdot 2$.

\section{Gel filtration of DPS}

The distribution of the component sugars between the core and O-specific side-chain regions can often be determined by fractionating the DPS, isolated from LPS by mild acid hydrolysis, by gel filtration (Wilkinson, 1977). As shown in Fig. 1, the elution profile for W. recta DPS was almost the same as that of the DPS of the typical Gram-negative bacterial LPS (Wilkinson, 1977), with three distinct peaks being eluted. If the results obtained by this gel filtration can be interpreted in the same way as those of other, similar experiments (reviewed by Wilkinson, 


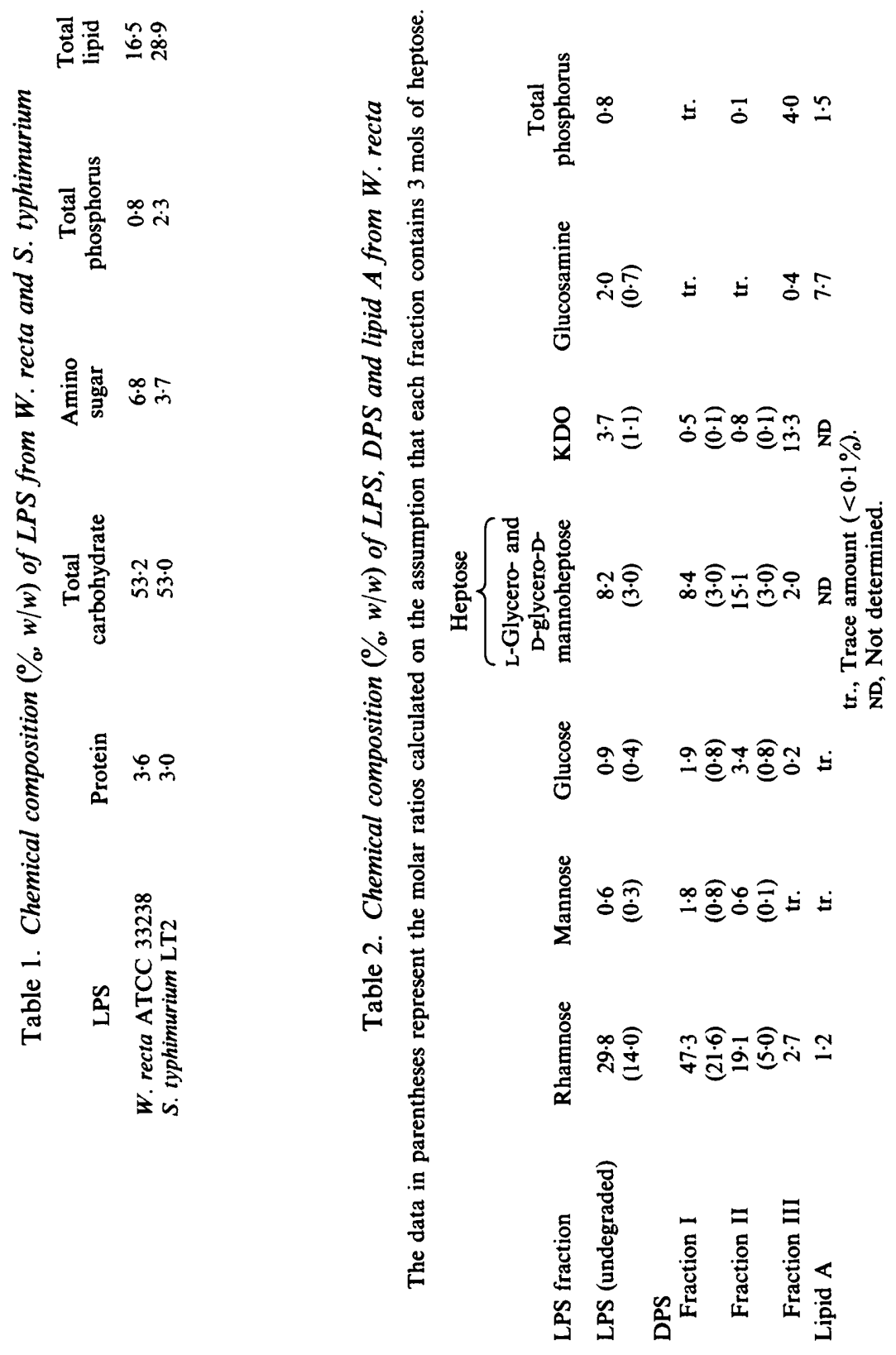




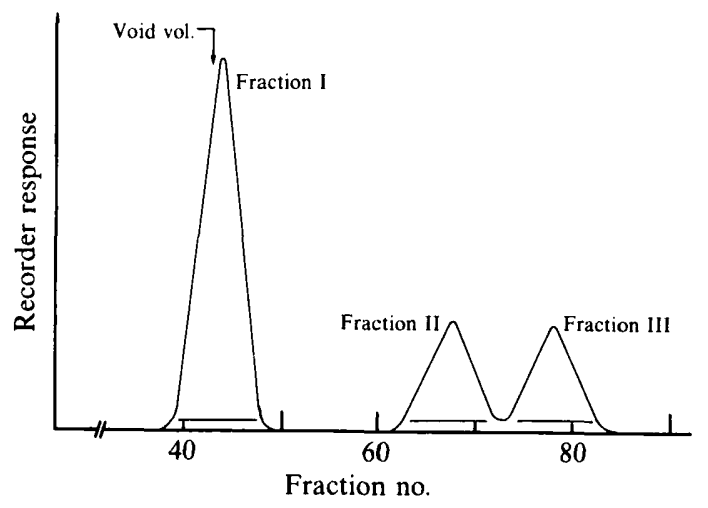

Fig. 1. Sephadex G-50 gel chromatography of the DPS fraction isolated from $W$. recta LPS. The elution profile is presented as the refractive index detector recorder response. The fractions shown by each horizontal line were pooled.

1977), the first peak (fraction I) corresponds to the polymeric $O$-side-chain with attached core, the second peak (fraction II) to the core oligosaccharide and the third peak (fraction III) to the monosaccharide fraction that contains KDO.

The results of sugar analyses of the three fractions obtained from DPS are in Table 2. Fraction II contained rhamnose, glucose and heptose in a molar ration of $5: 1: 3$ as the major sugar components and trace amounts of mannose and KDO, while fraction I contained, as predominant sugar components, rhamnose, mannose, glucose and heptose in a molar ratio of $22: 1: 1: 3$ and trace amounts of KDO. These results indicate that the O-specific chain of the LPS of this species consists of as much as 22 mols of rhamnose per 3 mols of heptose, while the core region consists of $1 \mathrm{~mol}$ of glucose, $3 \mathrm{mols}$ of heptose and presumably $1 \mathrm{~mol}$ or more of KDO. Furthermore, GLC analysis revealed that the heptose component of fraction I and II consisted of L-glycero- and D-glycero-D-mannoheptose in molar ratios of $2: 1 \cdot 2$ and $2: 1 \cdot 1$, respectively. Thus, 2 mols of L-glycero-D-mannoheptose and 1 mol of D-glycero-D-mannoheptose are present as the heptose constituent in the core region of $W$. recta LPS.

With regard to the mannose component, it is hard to explain why only trace amounts of mannose were found in fraction II corresponding to the core whereas $1 \mathrm{~mol}$ of mannose was found in fraction I corresponding to the $\mathrm{O}$-specific side-chain with attached core. In fraction II, 5 mols of rhamnose per 3 mols of heptose were found, suggesting that the core oligosaccharide substituted with a short chain of rhamnose was eluted in this fraction, but not in fraction I, probably because of its small molecular size. Fraction III contained free KDO (13.3\%), released from LPS during treatment with $5 \%$ acetic acid for the preparation of DPS.

\section{$S D S-P A G E$ analysis}

Electrophoretic banding patterns of LPS in SDS-PAGE have been useful in studying the heterogeneity and structure of LPS molecules of several genera of Gram-negative bacteria (Hitchcock et al., 1986). As shown in Fig. 2, S. typhimurium LT2 LPS (lane 2) showed the characteristic pattern that originates from the number of repeating units composed of $\mathrm{O}$-specific side-chains in the LPS molecules, at least 30 bands being observed with the smooth-type LPS. This result was consistent with that of Goldman \& Leive (1980). S. minnesota R595 (Re mutant) LPS consisting of lipid A and three molecules of KDO showed only a single rapidly migrating band (Fig. 2, lane 3). The electrophoretic behaviour of $W$. recta LPS (Fig. 2, lane 1) differed from that of LT2 LPS in that only a fast-migrating band and a few bands near the middle of the gel were observed. The fast-migrating band was believed to correspond to the LPS molecule lacking an $O$-specific side-chain and the few bands near the middle of the gel to correspond to smooth- 


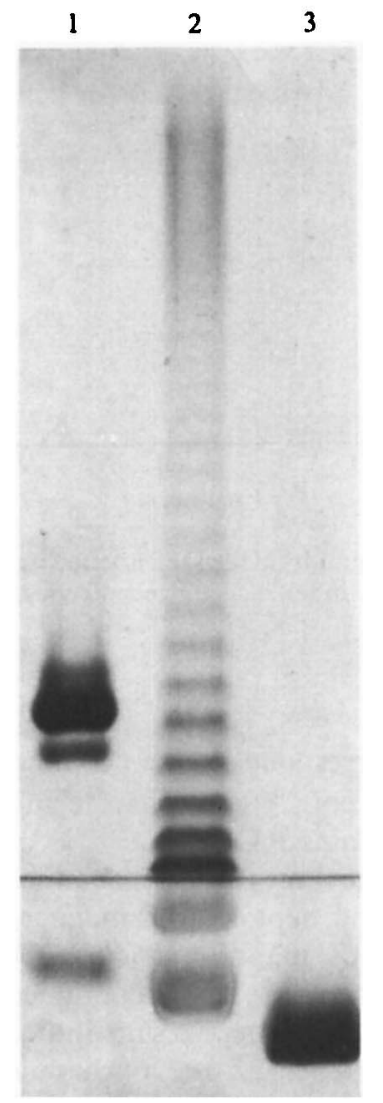

Fig. 2. SDS-PAGE patterns of LPSs from $W$. recta ATCC 33238 (1 $\mu \mathrm{g}$; lane 1), S. typhimurium LT2 (8 $\mu \mathrm{g}$; lane 2) and $S$. minnesota R595 (Re mutant) (4 $\mu \mathrm{g}$; lane 3).

type LPS possessing an $O$-specific side-chain. Furthermore, from a comparison of the patterns obtained by SDS-PAGE and by gel filtration for $W$. recta LPS, it was considered that the fastmigrating band in SDS-PAGE represents fraction II (core fraction) in gel filtration, and that the middle bands represent fraction I ( $O$-specific side-chain fraction with attached core). The molecular size of the core region of $W$. recta LPS, containing 5 mols of rhamnose per 3 mols of heptose, was slightly bigger than that of $S$. typhimurium LT2 LPS as the front band in SDSPAGE for $W$. recta LPS had a lower mobility than that of $S$. typhimurium LT2 LPS.

As described above, the $O$-specific side-chain of $W$. recta LPS contained a polymer of rhamnose. It is well-known that a number of ladder bands are detected by SDS-PAGE for smooth-type LPS of $S$. typhimurium because individual LPS molecules with $O$-specific sidechains differing in size by multiple increments of oligosaccharide repeating units (Hitchcock, 1983). However, this characteristic heterogeneity was not seen with $W$. recta LPS. These results suggest that the chain-lengths of the $O$-specific side-chains of $W$. recta LPS are considerably more homogeneous than those of $S$. typhimurium LT2 LPS.

\section{Fatty acid composition of lipid $A$}

Lipid A contained $53 \%$ total lipid (Table 2). The non-hydroxylated fatty acids found were as follows: $\mathrm{C}_{12: 0}(5.5 \%)$ and $\mathrm{C}_{14: 0}(16.2 \%)$ as the major components, and small amounts of $\mathrm{C}_{14: 1}$ $(2.4 \%), C_{16: 0}(1.5 \%)$ and $C_{16: 1}(1.8 \%)$ as additional minor components. In addition, large 
Table 3. Minimum doses of LPS, lipid A and DPS inducing Limulus amoebocyte lysate clotting activity and the Schwartzman reaction

$\begin{array}{lcc}\text { Stimulant } & \overbrace{\begin{array}{c}\text { Limulus } \\ \left(\mathrm{pg} \mathrm{m}^{-1}\right)\end{array}}^{\text {Minimum inducing dose }} \\ \begin{array}{c}\text { Schwartzman } \\ (\mu \mathrm{g} \text { per site })\end{array} \\ \begin{array}{l}\text { recta ATCC } 33238 \\ \text { LPS }\end{array} & 10 & 10 \\ \text { Lipid A } & 100 & 100 \\ \text { DPS } & 100000 & -* \\ \text { S. typhimurium LPS } & 100 & 10\end{array}$

* No haemorrhagic necrosis induced by a dose of $100 \mu \mathrm{g}$ per site.

Table 4. Mitogenic responses of $\mathrm{C} 3 \mathrm{H} / \mathrm{HeN}$ mouse spleen cells to LPS, lipid $\mathrm{A}$ and DPS

Data are expressed as the mean of the stimulation index \pm SE of triplicate cultures. Concanavalin $A$ $\left(5 \mu \mathrm{g} \mathrm{ml}^{-1}\right)$ was mitogenic for $\mathrm{C} 3 \mathrm{H} / \mathrm{HeN}$ spleen cells $(39 \cdot 0 \pm 2 \cdot 7)$.

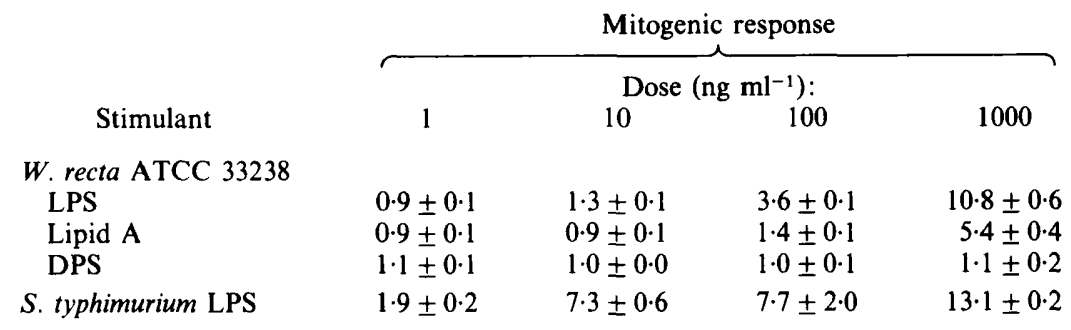

amounts of two hydroxylated fatty acids, $3-\mathrm{OH}-\mathrm{C}_{14.0}(29 \cdot 5 \%)$ and $3-\mathrm{OH}-\mathrm{C}_{16: 0}(43 \cdot 1 \%)$, were found. $W$. recta lipid A therefore resembles the lipid $\mathrm{A}$ of the Gram-negative obligately anaerobic filamentous bacterium Fusobacterium nucleatum, which also contains the above hydroxylated fatty acids as major components. This is of interest as lipid A is one of the potential pathogenic factors in periodontal disease and $F$. nucleatum is prominent in the bacterial flora of subgingival plaques. However, $W$. recta lipid A also contained glucosamine and total phosphorus in an approximate molar ratio of $1: 1$ (Table 2), indicating that it probably possesses the same diglucosaminide backbone phosphorylated at the 1 and $4^{\prime}$ positions as that found commonly in the lipid A of the LPS of Enterobacteriaceae.

\section{Biological activities}

The endotoxic activities of LPS, DPS and lipid A from $W$. recta were examined using the Limulus amoebocyte and dermal Schwartzman tests. The results are expressed as the coincident values in triplicate experiments (Table 3). S. typhimurium LPS was used as a control in both bioassays.

In the Limulus amoebocyte test LPSs from $W$. recta and $S$. typhimurium strongly activated the clotting enzyme; the minimum doses for these LPS-induced positive reactions were 10 and $100 \mathrm{pg} \mathrm{m}^{-1}$, respectively. However, $W$. recta lipid A had a slightly weaker activity $\left(100 \mathrm{pg} \mathrm{ml}^{-1}\right)$ than the LPS, and the $W$. recta DPS did not significantly activate the enzyme at the concentration $\left(100 \mathrm{ng} \mathrm{ml}^{-1}\right)$ used.

In the dermal Schwartzman reaction, the minimum doses of LPSs from both $W$. recta and $S$. typhimurium that caused haemorrhagic necrosis were $10 \mu \mathrm{g}$ per site; the minimum dose $(100 \mu \mathrm{g}$ per site) of lipid A was lower than that of $W$. recta LPS. Moreover, the DPS of $W$. recta did not induce the Schwartzman phenomenon.

The mitogenic activities of $W$. recta LPS, DPS and lipid A, and $S$. typhimurium LPS as a positive control, were determined in spleen cells of $\mathrm{C} 3 \mathrm{H} / \mathrm{HeN}$ and $\mathrm{C} 3 \mathrm{H} / \mathrm{HeJ}$ mice. The results 
are expressed as the arithmetic mean of the stimulation index (c.p.m. for tested culture/c.p.m. for culture with medium alone $=329 \pm 24$ c.p.m.). All fractions except $W$. recta DPS were strongly mitogenic for $\mathrm{C} 3 \mathrm{H} / \mathrm{HeN}$ murine spleen cells at concentrations between $10 \mathrm{ng} \mathrm{ml}^{-1}$ and $1 \mu \mathrm{g} \mathrm{ml}^{-1}$ (Table 4), whereas none were mitogenic for spleen cells of $\mathrm{C} 3 \mathrm{H} / \mathrm{HeJ}$ mice at any dose tested. Similarly to the other two endotoxic activities, the minimum dose of lipid A $\left(1 \mu \mathrm{g} \mathrm{ml}^{-1}\right)$ causing a positive reaction was lower than that of $W$. recta LPS $\left(100 \mathrm{ng} \mathrm{ml}^{-1}\right)$; DPS was not mitogenic at the doses used. $W$. recta LPS was strongly mitogenic for BALB/c and BALB/c $(\mathrm{nu} / \mathrm{nu})$ murine spleen cells (data not shown). The above results indicate that $W$. recta LPS is a B-cell mitogen in murine spleen cells.

These immunological characters of $W$. recta LPS may play aetiological roles in the progression of periodontal disease.

This work was partially supported by Grant nos 60570860 and 61771426 from the Japanese Ministry of Education, Science and Culture.

\section{REFERENCES}

BRADFORD, M. M. (1976). A rapid and sensitive method for the quantitation of microgram quantities of proteins utilizing the principle of protein-dye binding. Analytical Biochemistry 72, 248-254.

Chung, C. P., Nisengard, R. J., Slots, J. \& Genco, R. J. (1983). Bacterial IgG and IgM antibody titres in acute necrotizing ulcerative gingivitis. Journal of Periodontology 54, 557-562.

Dubois, M. L., Gilles, K. A., Hamilton, J. K., Rebers, P. A. \& SMITH, F. (1956). Colorimetric methods for determination of sugars and related substances. Analytical Chemistry 28, 350-356.

Dzink, J. L., Tanner, A. C. R., Haffajee, A. D. \& Socransky, S. S. (1985). Gram negative species associated with active destructive periodontal lesions. Journal of Clinical Periodontology 12, 648-659.

Galanos, C., LÜderitz, O. \& WestPhal, O. (1969). A new method for the extraction of $R$ lipopolysaccharides. European Journal of Biochemistry 9, 245-249.

Goldman, R. C. \& LeIVE, L. (1980). Heterogeneity of antigenic side-chain length in lipopolysaccharide from Escherichia coli $\mathrm{O} 111$ and Salmonella typhimurium LT2. European Journal of Biochemistry 107, 145153.

Grenier, D. \& Mayrand, D. (1986). Nutritional relationships between oral bacteria. Infection and Immunity 53, 616-620.

Haeffner, N., Chaby, R. \& Szabo, L. (1977). Identification of 2-methyl-3-hydroxydecanoic and 2methyl-3-hydroxytetradecanoic acids in the 'lipid X' fraction of the Bordetella pertussis endotoxin. European Journal of Biochemistry 77, 535-544.

Hisatsune, K., Decourcy, S. J., JR \& Mudd, S. (1967). Studies on the carbohydrate-peptide fraction of the centrifugal supernatants of Staphylococcus aureus culture. Biochemistry 6, 586-594.

HITCHCOCK, P. J. (1983). Aberrant migration of lipopolysaccharides in sodium dodecylsulfate/polyacrylamide gel electrophoresis. European Journal of Biochemistry 133, 685-688.

HitchCOCK, P. J., Leive, L., MäKelÄ, H., Rietschel, E. Th., Strittmatter, W. \& Morrison, D. C. (1986). Lipopolysaccharide nomenclature - past, present, and future. Journal of Bacteriology 166, 699705 .
Iwanaga, S., Morita, T., Harada, T., Nakamura, S., Niwa, M., TaKada, K., KimUra, T. \& Sakakibara, S. (1978). Chromogenic substrates for horseshoe crab clotting enzyme. Its application for the assay of bacterial endotoxins. Haemostasis 7, 183-188.

Kumada, H., Watanabe, K., Umemoto, T., Kondo, S. \& HisATSUNE, K. (1987). Chemical and biological properties of lipopolysaccharides isolated from $\mathrm{Wo}$ linella recta and Selenomonas sputigena. Japanese Journal of Bacteriology 42, 342.

LAEMMLI, U. K. (1970). Cleavage of structural proteins during the assembly of the head of bacteriophage T4. Nature, London 227, 680-685.

Laine, R. A., Stelner, K. \& Hakomori, S. (1974). Isolation and characterization of membrane glycolipids. Methods in Membrane Biology 2, 228-244.

LisTGARTEN, M. A. (1982). Colonization of subgingival areas by motile rods and spirochetes: clinical implications. In Host-Parasite Interactions in Periodontal Diseases, pp. 112-120. Edited by R. J. Genco \& S. E. Mergenhagen. Washington, DC: American Society for Microbiology.

MoORe, W. E. C., Holdeman, L. V., Smibert, R. M., HASh, D. E., Burmeister, J. A. \& RANNeY, R. R. (1982). Bacteriology of severe periodontitis in young adult humans. Infection and Immunity 38, 1137-1148.

Moore, W. E. C., Holdeman, L. V., Cato, E. P., GoOD, I. J., SMith, E. P., RANNEY, R. R. \& Palcanis, K. G. (1984). Variation in periodontal floras. Infection and Immunity 46, 720-726.

OsBoRN, M. J. (1963). Studies of the Gram-negative cell walls. I. Evidence for the role of 2-keto-3deoxyoctonate in the lipopolysaccharide of Salmonella typhimurium. Proceedings of the National Academy of Sciences of the United States of America 50, 499-506.

RIETSCHEL, E. Th., GotTerT, H., LÜDERITZ, O. \& WestPhAL, O. (1972). Nature and linkages of the fatty acids present in the lipid-A component of Salmonella lipopolysaccharides. European Journal of Biochemistry 28, 166-173.

Rietschel, E. Th., WollenWeber, H. W., Brade, H., ZÄHRINGER, U., LINDNER, B., SEYDEL, U., BRADACZEK, H., BARNICKEL, G., LABISCHINSKY, H. \& GiesBrecht, P. (1984). Structure and conformation 
of the lipid A component of lipopolysaccharides. In Handbook of Endotoxin, vol. 1, pp. 187-220. Edited by R. A. Proctor. Amsterdam: Elsevier.

SavitT, E. D. \& SocranSKY, S. S. (1984). Distribution of certain subgingival microbial species in selected periodontal conditions. Journal of Periodontal Research 19, 111-123.

SLOTS, J. (1982). Importance of black-pigmented Bacteroides in human periodontal disease. In HostBacterial Interactions in Periodontal Disease, pp. 27 45. Edited by R. J. Genco \& S. E. Mergenhagen. Washington, DC: American Society for Microbiology.

TANNER, A. C. R., SOCRansky, S. S. \& Goodson, J. M. (1984). Microbiota of periodontal pockets losing crestal alveolar bone. Journal of Periodontal Research 19, 279-291.

TsaI, C.-M. \& Frasch, C. E. (1982). A sensitive silver stain for detecting lipopolysaccharides in polyacrylamide gels. Analytical Biochemistry 119, 115-119.

WeISSBACH, A. \& HURWITZ, J. (1959). The formation of 2-keto-3-deoxyheptonic acid in extracts of Escherichia coli B. Journal of Biological Chemistry 234, 705709.

WeSTPHAL, O. \& JANN, K. (1966). Bacterial lipopolysaccharides: extraction with phenol-water and further applications of the procedure. Methods in Carbohydrate Chemistry 5, 83-91.

WestPhAL, O., LÜDERITZ, O. \& Bister, R. (1952). Über die Extraction von Bakterien mit Phenol/ Wasser. Zeitschrift für Naturforschung 7b, 148-155.

WhEAT, R. W. (1966). Analysis of hexosamines in bacterial polysaccharide by chromatographic procedures. Methods in Enzymology 8, 60-75.

WiLkinson, S. G. (1977). Composition and structure of bacterial lipopolysaccharides. In Surface Carbohydrates of the Prokaryotic Cell, pp. 97-175. Edited by I. W. Sutherland. New York: Academic Press.

ZAMbon, J. J., Christersson, L. A. \& Slots, J. (1983). Actinobacillus actinomycetemcomitans in human periodontal disease. Journal of Periodontology 54, 707-711. 